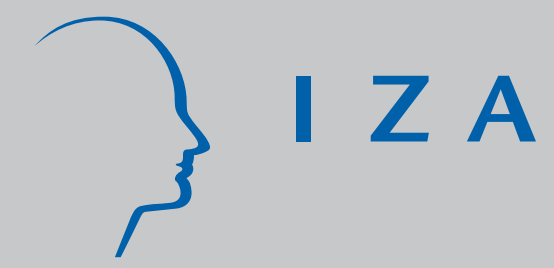

IZA DP No. 1130

Self-Employed Immigrants in Denmark and Sweden: A Way to Economic Self-Reliance?

PernillaAndersson

Eskil Wadensjö

April 2004 


\title{
Self-Employed Immigrants in Denmark and Sweden: A Way to Economic Self-Reliance?
}

\author{
Pernilla Andersson \\ Swedish Institute for Social Research, \\ Stockholm University \\ Eskil Wadensjö \\ Swedish Institute for Social Research, \\ Stockholm University and IZA Bonn
}

\section{Discussion Paper No. 1130 April 2004}

IZA

\author{
P.O. Box 7240 \\ 53072 Bonn \\ Germany
}

Phone: +49-228-3894-0

Fax: +49-228-3894-180

Email: iza@iza.org

\begin{abstract}
Any opinions expressed here are those of the author(s) and not those of the institute. Research disseminated by IZA may include views on policy, but the institute itself takes no institutional policy positions.

The Institute for the Study of Labor (IZA) in Bonn is a local and virtual international research center and a place of communication between science, politics and business. IZA is an independent nonprofit company supported by Deutsche Post World Net. The center is associated with the University of Bonn and offers a stimulating research environment through its research networks, research support, and visitors and doctoral programs. IZA engages in (i) original and internationally competitive research in all fields of labor economics, (ii) development of policy concepts, and (iii) dissemination of research results and concepts to the interested public.
\end{abstract}

IZA Discussion Papers often represent preliminary work and are circulated to encourage discussion. Citation of such a paper should account for its provisional character. A revised version may be available on the IZA website (www.iza.org) or directly from the author. 
IZA Discussion Paper No. 1130

April 2004

\section{ABSTRACT \\ Self-Employed Immigrants in Denmark and Sweden: A Way to Economic Self-Reliance?*}

Immigrants have a weak position in the labour market in most European countries. Many have difficulties in establishing themselves in the labour market, the employment rate is low and the hourly wages are generally lower than what could be expected from characteristics (age, gender, education). Many have to rely on the social transfer payments including social assistance. One way to avoid the problems in getting a job is to become self-employed. In this paper we make use of two large data-sets to study self-employment among immigrants in Denmark and Sweden. The three main issues covered are 1) if the immigrants are overrepresented among the self-employed, 2) the characteristics of self-employed immigrants, and 3) the incomes of the self-employed immigrants. In each case we compare the situation in the two countries. The immigrants, especially immigrants from non-Western countries, are overrepresented among the self-employed in both countries. The selfemployed immigrants in both countries have relatively low incomes, lower than natives with the corresponding characteristics.

JEL Classification: J15, J23, J61

Keywords: immigrant workers, self-employment

Corresponding author:

Eskil Wadensjö

Swedish Institute for Social Research

Stockholm University

10691 Stockholm

Sweden

Email: Eskil.Wadensjo@sofi.su.se

\footnotetext{
* We would like to thank seminar participants at the ESPA-net conference in Copenhagen in November 2003 for helpful comments. Financial support from IFAU and the Rockwool Foundation is gratefully acknowledged.
} 


\section{Introduction}

Immigrants have a weak position in the labour market in most European countries. Many have difficulties in establishing themselves in the labour market, the employment rate is low and the hourly wages are generally lower than what could be expected from characteristics (age, gender, education). Many have to rely on the social transfer payments including social assistance. One way to avoid the problems in getting employment is to become self-employed. In some countries there are also systems for supporting the establishment of self-employment for unemployed. In this paper we make use of two large data-sets to study self-employed immigrants in Denmark and Sweden. We cover three issues. The first issue is if the immigrants are overrepresented among the employed in the two countries. The second issue is what characterizes the self-employed immigrants, and the third issue is the incomes of the immigrants. We compare immigrants and natives and the situation in the two countries.

In section 1 we present earlier studies in the field, in section 2 we motivate why a comparison between Denmark and Sweden is of interest and give some background information on immigration to the two countries, in section 3 we present the data, section 4 presents our results and section 5 summarizes the results and some conclusions are drawn.

\section{Research on immigrants and self-employment ${ }^{1}$}

The question why immigrants become and are self-employed has been dealt with in various studies. We will start by giving a brief description of the hypotheses put forward in the literature concerning this question. Theories are found both in the sociology and the economics literature that explain why individuals in general, and immigrants in particular, become self-employed.

The basic explanation of the choice of becoming self-employed is that the expected earnings from having one's own business are higher than the expected earnings from an employment. A higher incidence of self-employment could either be explained by that

\footnotetext{
${ }^{1}$ For more thorough descriptions of theories, explanations and results, see for example Blume Jensen et al. (2004), Fairlie and Meyer (1996) and Ekberg and Hammarstedt (1999).
} 
the group has characteristics, or is treated in the economy in a way that is favourable regarding the prospects of income from self-employment, or by that members of the group have relatively unfavourable prospects regarding income (employment, wage level) from being an employee.

Economists often try to explain the high shares of self-employment among certain groups of immigrants by claiming that they are more likely to have certain characteristics that promote self-employment. Such characteristics are (higher) managerial skills [Lucas (1978)], (less) risk aversion [Kihlstrom and Laffont (1979)], and (less binding) wealth and liquidity constraints [Evans and Jovanovic (1989) and Lindh and Ohlsson (1996)]. Another economic motive behind the decision of becoming self-employed, suggested by Yuengert (1995), is the so called "tax avoidance hypothesis". If immigrants on average face higher taxes, they may become more interested in becoming self-employed. The motive would be that this form of employment entails better ways of avoiding taxes. Another hypothesis is that immigrants have ethnic resources which promote selfemployment. $^{2}$ Such ethnic resources are traditions and possible experience of selfemployment in the home country, sector-specific human capital which makes it easier to run a business among immigrants from the same region and ability to provide special goods demanded by co-ethnics.

The explanations mentioned above build on that some people have a higher possibility to succeed as self-employed. The reasons may be higher managerial skills, less risk aversion or ethnic net-work resources. Other explanations build on that some people have fewer possibilities of getting a job or getting a well-paid job and therefore turn to selfemployment. Immigrants on average experience more difficulties in getting jobs (lower labour force participation and employment rates) and receive lower pay given characteristics. This could be explained by discrimination. Moore's (1983) discussion of employer discrimination against immigrants is summarized in the so-called “disadvantage hypothesis". In essence, immigrants have difficulties gaining employment due to discrimination and therefore tend to choose alternative employment such as selfemployment to a larger extent than natives do. If this is the explanation one would expect

\footnotetext{
${ }^{2}$ The approach is put forward in Light (1984) and summarized in Fairlie and Meyer (1996).
} 
immigrants to be overrepresented among the group of self-employed compared to their share among the employees. However, Fairlie and Meyer (1996) argue that this hypothesis cannot explain the often observed large differences in the self-employment rate between different groups of immigrants. Borjas and Bronars (1989) try to explain differences in incomes for the self-employed by consumer, rather than employer, discrimination. Another explanation is that the minimum wage (set by law or, as in the Scandinavian countries, by collective agreements) is so high that the demand for people with low education and low skills became smaller than the supply, and that the immigrants are overrepresented in that group. Underbidding is not a possible method of getting a job due to the institutional set-up, but self-employment with a low hourly income may be a way to get an income without relying on the social transfer system.

There are a number of studies of the factors that cause people to be or become selfemployed. The general hypothesis that those who have more to gain by being selfemployed compared to being employed are more often self-employed, is supported for example by Borjas (1986) studying the U.S. and Clark and Drinkwater (2000) studying England and Wales.

Clark and Drinkwater also get support for the hypothesis that traditions regarding selfemployment are of importance. Those who come from a cultural (religious) background that is supportive of self-employment more often are self-employed. Another result is that those with poorer knowledge of English less often are self-employed than those with better knowledge of English and, a bit surprising, that those who live in ethnic enclaves are underrepresented among the self-employed.

In a study of male immigrants and natives in Denmark, Dohlmann (2001) shows that the experience of unemployment is a factor that influences the propensity to become selfemployed. Her study also shows that unemployed immigrants more often become selfemployed than unemployed natives.

Different studies from Denmark, Sweden, and other countries show that there are large differences between the propensity to become and to be self-employed among different ethnic groups. A study by Rezaei (2002) shows that the share, maybe a bit surprising, is highest among immigrants who come from the Netherlands (many of them are farmers). 
But the share of self-employed is also high among immigrants from China, India, Pakistan and Iran for example.

The incomes of self-employed immigrants have been covered by several studies. In a study of Denmark, Bager (2002) shows that the incomes of the self-employed immigrants are lower than the incomes of those immigrants who are employees. The pattern is the opposite for natives. This is an indication that the reasons for becoming self-employed may differ between natives and immigrants.

\section{Denmark and Sweden - two immigration countries}

Up to WW1 Denmark and Sweden were countries of emigration. In the inter-war period neither immigration nor emigration was extensive. Sweden became a net-immigration country already in the 1940s. Refugees arrived during WW2 and labour force immigration started in the late 1940s. Denmark had a net-emigration in the first decades of the post-war period but turned to be a net-immigration country in the late 1960s. In the 1970s the immigration changed in both countries from being mainly labour force immigration to an immigration of refugees. Now both Denmark and Sweden have a large foreign-born population and a rapidly increasing number of second generation immigrants. In this section we will start by giving an overview of the immigration history of the two countries.

In practice, Sweden became an immigration country already during WW2 when many refugees arrived to Sweden. Most refugees returned after the war but a good number remained in Sweden, as for example many refugees from Estonia. In the business peak of the late 1940s, a policy of actively recruiting foreign workers to the Swedish manufacturing industry started. In the 1950s immigration from the neighbouring countries became important, especially from Finland. In the 1960s the immigration from Finland continued but many people also arrived from countries like Yugoslavia, Greece, and Turkey. After reaching a record level in 1970, the immigration became smaller partly as a result of higher unemployment in Sweden, partly as a result of stricter rules for being accepted as a labour migrant. On the other hand the number of refugees arriving in Sweden increased. In the 1970s many arrived from Latin America, from the 1980s on 
many came from the Middle East and Iran, and in the 1990s the former Yugoslavia and Africa were the home countries of many refugees. To that should be added a gradually increasing inflow of family members to earlier arrived labour migrants and refugees. Sweden is now a country with a large foreign-born population with origins in many parts of the world and the second generation of immigrant is a fast growing group.

Denmark was a net-emigration country in the first two decades after WW2. Many moved to Sweden. The second largest group of immigrants in Sweden was the Danish one. For many years, Denmark had a higher unemployment rate than Sweden. However, in the 1960s the unemployment became very low also in Denmark and a period of labour immigration began. People were coming from Mediterranean countries but also from countries in South Asia. The labour immigration period was short in Denmark. With the oil crisis in 1973 the labour market situation and also the policy changed. But the immigration continued in the same way as in Sweden. Like Sweden, most of the new arrivals have been either refugees or family members to earlier labour immigrants or refugees. The immigrants are mainly from the same countries as those who have arrived to Sweden. Denmark is now, again like Sweden, a country with a large foreign born population. The immigrant (first generation) share of the population is, however, only half the size of that in Sweden, 6 per cent compared to 12 per cent. The number of second generation immigrants is relatively smaller in Denmark than in Sweden due to that the immigration to Denmark started later than that to Sweden.

Denmark and Sweden have many things in common, but there are differences in the regulation of the labour markets and they have experienced rather different business cycles and immigration trends. ${ }^{3}$ It is of interest to compare Sweden and Denmark to see if the differences in labour market regulation and immigration mean that there are large differences concerning self-employment among immigrants.

\footnotetext{
${ }^{3}$ See Blume et al. (2003) for a comparative study on poverty among immigrants in Denmark and Sweden.
} 


\section{Data}

The study is based on data from two different sources. We use the Danish Ministry of Economic Affairs' Law Model for 1999 for individuals who live in Denmark. ${ }^{4}$ This database contains detailed information on 3.3 percent of the population living in Denmark. After imposing restrictions on the sample we have a population of 77438 employed individuals. Of them 3967 individuals or 5.1 per cent are self-employed. For Sweden we use data from the register-based labour market statistics (RAMS). ${ }^{5}$ We have information on all individuals living in Sweden in December 1999. To make the Swedish data comparable in size with the Danish population, a 2.6 percent sample was taken from the RAMS database. The Swedish sample contains, after several restrictions are imposed, 87105 employed individuals. About 3.5 per cent, or 3033 individuals are self-employed. Throughout the present study, self-employed are defined as those who do not have any wage income but only income from self-employment. ${ }^{6}$ It means that those who in the year have income both from self-employment and from being an employee are not counted as self-employed. Since the two databases are not designed in the same way a lot of work had to be done to make the information comparable. Below we give a description of some variables that deserve extra attention regarding how they are defined.

\subsection{First and second generation immigrants}

The aim of this paper is firstly to study the probability for first and second generation immigrants to be self-employed, and secondly to study the incomes of self-employed immigrants compared to those with other forms of employment, and compared to selfemployed natives. We have divided the countries of origin into two categories; Western and non-Western countries. Western countries are defined as EU-countries, the Nordic countries, North America and Oceania. Non-Western countries are all other countries. One difference between the Danish and the Swedish data could not be avoided. In the Danish data set Switzerland is classified as a Western country, but in the Swedish data

\footnotetext{
${ }^{4}$ See Ministry of Economic Affairs (2000) for a presentation of the database.

${ }^{5}$ See Statistics Sweden (1999) for information about the database.

${ }^{6}$ Only employed individuals between 18 and 64 years of age are included. Farmers are excluded from the regressions but included in the descriptive statistics.
} 
set as a non-Western country. There are only a few immigrants from Switzerland so this difference in definition does not cause any major problems.

As can be seen from table 1 the immigrants' share of the total population is higher in Sweden than in Denmark. This is true for immigrants from both regions. Immigrants in Sweden are more equally distributed between the two regions than in Denmark. The high share of Western immigrants in Sweden is explained by the large number of people who migrated to Sweden in the 1960s and 1970s from Western countries, especially from Finland.

Table 1. Employed natives and immigrants in the samples from both countries

\begin{tabular}{cccc}
\hline $\begin{array}{l}\text { Born in } \\
\text { Denmark }\end{array}$ & $\begin{array}{c}\text { Western } \\
\text { Immigrants }\end{array}$ & $\begin{array}{l}\text { Non-Western } \\
\text { immigrants }\end{array}$ & All \\
\hline 74560 & 960 & 1918 & 77438 \\
$96.28 \%$ & $1.24 \%$ & $2.48 \%$ & $100.0 \%$ \\
\hline Born in & $\begin{array}{l}\text { Western } \\
\text { immigrants }\end{array}$ & $\begin{array}{l}\text { Non-Western } \\
\text { immigrants }\end{array}$ & All \\
\hline 79215 & 3939 & 3951 & 87105 \\
$90.94 \%$ & $4.52 \%$ & $4.54 \%$ & $100.0 \%$ \\
\hline
\end{tabular}

In table 2 and 3 a more detailed description of the various groups of first and second generation immigrants is given. In the Swedish data set there are a number of individuals who were born in Sweden but whose parents' country of birth is unknown. In the regressions they have been coded as natives, i.e. they have been included in the same category as those who were born in Sweden and whose parents also were born in Sweden. 
Table 2. Employed individuals in the Swedish sample according to migration status

\begin{tabular}{lcc}
\hline Group & $\mathrm{N}$ & $\%$ \\
\hline \hline Native Swedes & 71561 & 82.15 \\
$\begin{array}{l}\text { Second generation - one Swedish parent and one parent from a } \\
\text { Western country }\end{array}$ & 4217 & 4.84 \\
$\begin{array}{l}\text { Second generation - one Swedish parent and one parent from a } \\
\text { non-Western country }\end{array}$ & 807 & 0.93 \\
Immigrants from Western countries & 3939 & 4.52 \\
Second generation - both parents from Western countries & 1511 & 1.73 \\
Immigrants from non-Western countries & 3951 & 4.54 \\
Second generation - both parents from non-Western countries & 473 & 0.54 \\
Second generation - both parents from unknown countries* & 646 & 0.75 \\
\hline \hline Total & 87105 & 100.00 \\
\hline$*$ Coded as natives in the regressions. & &
\end{tabular}

Table 3. Employed individuals in the Danish sample according to migration status

\begin{tabular}{lcc}
\hline Group & $\mathrm{N}$ & $\%$ \\
\hline \hline Native Danes & 73268 & 94.62 \\
$\begin{array}{l}\text { Second generation - one Danish parent and one parent from a } \\
\text { Western country }\end{array}$ & 1043 & 1.35 \\
$\begin{array}{l}\text { Second generation - one Danish parent and one parent from a } \\
\text { non-Western country }\end{array}$ & 193 & 0.25 \\
$\begin{array}{l}\text { Immigrants from Western countries } \\
\text { Second generation - both parents from Western countries }\end{array}$ & 960 & 1.24 \\
$\begin{array}{l}\text { Immigrants from non-Western countries } \\
\text { Second generation - both parents from non-Western countries }\end{array}$ & 1918 & 0.03 \\
\hline \hline Total & 30 & 0.04 \\
\hline
\end{tabular}




\subsection{Definition of self-employed}

The identification of self-employed in the Swedish data is made by using the variable "income from self-employment". One drawback of the Swedish data is that our definition of self-employed does not include those who have a limited liability company.

For individuals in the Danish data we use a variable of socioeconomic belonging to identify which individuals were self-employed in 1999. Self-employed with or without employees are included, as well as their spouses if they have been employed in the firm. The incomes for this group are defined as the difference between the total income from labour during the year and wages. If this difference is zero but the individual belongs to the appropriate socioeconomic group of self-employed he/she is still considered to be self-employed.

Table 4. Self-employed in the Danish and Swedish samples

\begin{tabular}{lcccc}
\hline Self-employed & $\begin{array}{c}\text { Born in host } \\
\text { country }\end{array}$ & $\begin{array}{c}\text { Western } \\
\text { immigrants }\end{array}$ & $\begin{array}{c}\text { Non-Western } \\
\text { immigrants }\end{array}$ & Total \\
\hline Living in Denmark & 3770 & 47 & 150 & 3967 \\
& $95.0 \%$ & $1.2 \%$ & $3.8 \%$ & $100.0 \%$ \\
\hline Living in Sweden & 2591 & 150 & 292 & 3033 \\
& $85.4 \%$ & $4.9 \%$ & $9.6 \%$ & $100.0 \%$ \\
\hline
\end{tabular}

\subsection{Definition of education}

When comparing two different countries we have to keep in mind the differences in educational systems between them. In the regressions which are separately estimated for individuals living in Denmark and Sweden we include the country specific educational level. ${ }^{7}$ When using the merged data a slightly different definition is used. Here we only use four different categories; primary school, upper secondary school, short higher education and long higher education.

\footnotetext{
${ }^{7}$ For Sweden the levels are: primary school less than 9 years, primary school 9 (10) years, upper secondary less than 2 years, upper secondary 2 years or more, higher education less than 3 years, higher education 3 years or more, and post-graduate education. For Denmark the levels are: primary school, upper secondary school, vocational education, short higher education, medium-length higher education, and long higher education.
} 


\section{Results}

\subsection{Descriptive statistics for the self-employed}

We will start with some descriptive information for the two populations studied. Two tables with descriptive statistics are shown below. In Table 5 we compare those living in Denmark with those living in Sweden. The similarities in the two populations are very large. Three differences are worth noting. First, the share of self-employed is 1.6 percentage points higher in Denmark than in Sweden. Second, there is almost a 20 percentage points difference in the share that is married. This is explained by that in the Danish data, but not in the Swedish data, cohabiting couples living together with children have been coded as married. Third, the share of individuals who were born in Denmark/ Sweden and have one parent from this country and another from a Western country is much higher in Sweden than in Denmark. The large number of immigrants arriving in Sweden from Western countries in the 1950s and the 1960s is the main explanation for this difference. 
Table 5. Descriptive statistics (employed aged 18-64)

\begin{tabular}{lrr}
\hline Variables & Denmark & Sweden \\
\hline Age & 41.0 & 41.8 \\
Female & $46.9 \%$ & $46.1 \%$ \\
Self-employed & $5.1 \%$ & $3.5 \%$ \\
One parent born in host country, one in a Western country & $1.3 \%$ & $4.8 \%$ \\
One parent born in host country, one in a non-Western & & \\
country & $0.2 \%$ & $0.9 \%$ \\
Both parents born in a Western country & $0.03 \%$ & $1.7 \%$ \\
Both parents born in a non-Western country & $0.04 \%$ & $0.5 \%$ \\
Total born in a Western country & $1.2 \%$ & $4.5 \%$ \\
Born in a Western country - lived in host country for five & & \\
years or more & $0.8 \%$ & $4.2 \%$ \\
Born in a Western country - lived in host country for less & & \\
than five years & $0.4 \%$ & $0.3 \%$ \\
Total born in a non-Western country & $2.5 \%$ & $4.5 \%$ \\
Born in a non-Western country - lived in host country for & & \\
five years or more & $1.9 \%$ & $4.2 \%$ \\
Born in a non-Western country - lived in host country for & & \\
less than five years & $0.6 \%$ & $0.3 \%$ \\
Primary school & $25.9 \%$ & $19.9 \%$ \\
Upper secondary school (including vocational education) & $49.3 \%$ & $50.5 \%$ \\
Short higher education & $18.2 \%$ & $14.9 \%$ \\
Long higher education & $6.6 \%$ & $14.7 \%$ \\
Married & $72.5 \%$ & $49.4 \%$ \\
\hline Number of observations & 77438 & 87105 \\
\hline
\end{tabular}

In table 6 a description of the distribution of self-employed on industries in the two countries is presented. Inhabitants in each country are divided into those who were born in the country and those who are immigrants. In the agricultural sector there is a clear overrepresentation of natives in both. Since the agricultural sector has a long tradition and farms often are inherited within the family this is an obvious result. Immigrants in both countries are overrepresented in retailing and hotels and restaurants. In Denmark 31 per cent of self-employed immigrants run a hotel or a restaurant while only 3.8 per cent of natives in Denmark do so. ${ }^{8}$ For Sweden we have a similar situation. These figures correspond well to the general view in the two countries that a high share of selfemployed immigrants run a shop or own a smaller restaurant. In other industries it appears to be a more equal distribution for natives and immigrants.

\footnotetext{
${ }^{8}$ For more information on the distribution of immigrants on industries in Denmark, see Rezaei (2004).
} 
Table 6. Industry distribution in percent of self-employed in Denmark and Sweden

\begin{tabular}{lcccc}
\hline Industry & $\begin{array}{c}\text { Born in } \\
\text { Denmark }\end{array}$ & $\begin{array}{c}\text { Immigrants } \\
\text { living in } \\
\text { Denmark }\end{array}$ & $\begin{array}{c}\text { Born in } \\
\text { Sweden }\end{array}$ & $\begin{array}{c}\text { Immigrants } \\
\text { living in } \\
\text { Sweden }\end{array}$ \\
\hline Agriculture & 23.3 & 6.6 & 24.0 & 2.7 \\
Manufacturing & 6.7 & 2.5 & 7.3 & 5.6 \\
Public utilities & 0.1 & 0.0 & 0.0 & 0.0 \\
Construction & 11.9 & 2.5 & 13.9 & 5.9 \\
Retailing & 20.2 & 34.0 & 14.9 & 27.2 \\
Hotels and restaurants & 3.8 & 31.0 & 1.9 & 21.5 \\
Transport, storage, communications & 6.8 & 5.6 & 9.0 & 10.9 \\
Financial services & 0.2 & 0.5 & 0.0 & 0.0 \\
Real estate and rental services & 14.3 & 7.6 & 14.4 & 11.3 \\
Education & 0.7 & 1.0 & 0.8 & 0.4 \\
Health and social services & 6.2 & 3.5 & 2.4 & 1.8 \\
Public administration and other & & & & \\
social and private services & 5.7 & 5.1 & 11.3 & 12.7 \\
\hline Number of observations & 3770 & 197 & 2591 & 442 \\
\hline
\end{tabular}

\subsection{Probability of being self-employed in 1999 given that an individual is employed}

In this section we present the marginal effects according to three different probit estimations. ${ }^{9}$ It has been shown in earlier studies that immigrants, especially those from non-Western countries have a higher probability of being self-employed than natives. ${ }^{10}$ In this paper we add an additional dimension by comparing self-employed immigrants in Denmark and Sweden.

In separate regressions for the two countries the same pattern can be seen. In both the Danish and the Swedish data we find a positive significant effect on the probability to be self-employed for non-Western immigrants who have been in the host country for five years or more. For Sweden but not for Denmark, we find a positive effect also for Western immigrants who have been in the country for five years or more. The overrepresentation of immigrants among the self-employed is in line with the literature in the field. As these results have been found in several industrialized countries, the phenomenon is probably not explained by specific economic characteristics of the host country.

\footnotetext{
${ }^{9}$ In these regressions we have only included those with a positive income from self-employment.

${ }^{10}$ Here natives are defined as individuals who were born in the host country by parents born in the same country.
} 
The data from the two countries have been merged together in an attempt to compare Denmark and Sweden regarding self-employment a bit more closely. A result is that those living in Sweden are less likely to be self-employed than those living in Denmark. An explanation for this result can be that there is a long tradition of small businesses and self-employment in Denmark. First-generation and second-generation immigrants from non-Western countries have a higher probability to be self-employed than natives also according to the estimations based on the merged data set. 
Table 7. Marginal effects calculated for the probability of being self-employed in 1999. Farmers excluded. Standard errors in parentheses

\begin{tabular}{|c|c|c|c|c|c|c|}
\hline \multirow{2}{*}{$\begin{array}{l}\text { Variables } \\
\text { Living in Sweden }\end{array}$} & \multicolumn{2}{|c|}{ All } & \multicolumn{2}{|c|}{ Denmark } & \multicolumn{2}{|c|}{ Sweden } \\
\hline & -0.012 & $(0.0008)^{* * *}$ & & & & \\
\hline Age & 0.004 & $(0.0029)^{* * *}$ & 0.005 & $(0.0005)^{* * *}$ & 0.004 & $(0.0004)^{* * *}$ \\
\hline Age squared & -0.000 & $(0.0000)^{* * *}$ & -0.000 & $(0.0000)^{* * *}$ & -0.000 & $(0.0000)^{* * *}$ \\
\hline Female & -0.019 & $(0.0008)^{* * *}$ & -0.023 & $(0.0013)^{* *}$ & -0.015 & $(0.0010)^{* * *}$ \\
\hline $\begin{array}{l}\text { Both parents born in the host country } \\
\text { One parent born in host country, one in a }\end{array}$ & reference & & reference & & reference & \\
\hline Western country & 0.005 & $(0.0027)^{*}$ & 0.008 & $(0.0071)$ & 0.003 & $(0.0026)$ \\
\hline $\begin{array}{l}\text { One parent born in host country, one in a } \\
\text { non-Western country }\end{array}$ & 0.015 & $(0.0074)^{* *}$ & -0.005 & $(0.0147)$ & 0.016 & $(0.0075)^{* * *}$ \\
\hline Both parents born in a Western country & 0.003 & $(0.0051)$ & (dropped) & & 0.001 & $(0.004)$ \\
\hline $\begin{array}{l}\text { Both parents born in a non-Western } \\
\text { country }\end{array}$ & 0.031 & $(0.0125)^{* * *}$ & 0.104 & $(0.0780)^{* *}$ & 0.022 & $(0.0106)^{* * *}$ \\
\hline $\begin{array}{l}\text { Born in a Western country - lived in host } \\
\text { country for five years or more }\end{array}$ & 0.005 & $(0.0027)^{* *}$ & -0.001 & $(0.0064)$ & 0.006 & $(0.0026)^{* *}$ \\
\hline $\begin{array}{l}\text { Born in a Western country - lived in host } \\
\text { country for less than five years }\end{array}$ & 0.010 & $(0.0090)$ & 0.003 & $(0.0112)$ & 0.019 & $(0.0160)$ \\
\hline $\begin{array}{l}\text { Born in a non-Western country - lived in } \\
\text { host country for five years or more }\end{array}$ & 0.053 & $(0.0039)^{* * *}$ & 0.056 & $(0.0075)^{* * *}$ & 0.049 & $(0.0046) * * *$ \\
\hline $\begin{array}{l}\text { Born in a non-Western country - lived in } \\
\text { host country for less than five years }\end{array}$ & 0.020 & $(0.0088) * * *$ & 0.017 & $(0.0118)^{*}$ & 0.031 & $(0.0152)^{* * *}$ \\
\hline Primary school & 0.025 & $(0.0019) * * *$ & & & & \\
\hline Upper secondary school & 0.019 & $(0.0013)^{* * *}$ & & & & \\
\hline Short higher education & reference & & & & & \\
\hline Long higher education & 0.003 & $(0.0019)$ & & & & \\
\hline Primary school less than 9 years SE & & & & & 0.008 & $(0.0021)^{* * *}$ \\
\hline Primary school $9(10)$ years SE & & & & & 0.010 & $(0.0018)^{* * *}$ \\
\hline Upper secondary less than 2 years SE & & & & & reference & \\
\hline Upper secondary 2 years or more SE & & & & & 0.002 & $(0.0015)$ \\
\hline Higher education less than 3 years SE & & & & & -0.009 & $(0.0012)^{* * *}$ \\
\hline Higher education 3 years or more SE & & & & & -0.016 & $(0.0011)^{* * *}$ \\
\hline Post graduate education SE & & & & & -0.020 & $(0.0014)^{* * *}$ \\
\hline Primary school DK & & & -0.000 & $(0.0030)$ & & \\
\hline Upper secondary school DK & & & reference & & & \\
\hline Vocational education DK & & & 0.001 & $(0.0030)$ & & \\
\hline Short higher education DK & & & -0.008 & $(0.0033)^{* *}$ & & \\
\hline Medium-length higher education DK & & & -0.024 & $(0.0020)^{* * *}$ & & \\
\hline Long higher education DK & & & -0.000 & $(0.0036)$ & & \\
\hline Married & 0.004 & $(0.0009) * * *$ & 0.009 & $(0.0014) * * *$ & 0.002 & $(0.0010)^{*}$ \\
\hline Pseudo $\mathrm{R}^{2}$ & 0.0560 & & 0.059 & & 0.0557 & \\
\hline Number of observations & 161126 & & 75540 & & 85560 & \\
\hline
\end{tabular}

Note: *** Significant at the $1 \%$ level. ** Significant at the 5\% level. * Significant at the $10 \%$ level. 


\subsection{Incomes from self-employment; how good are they compared to incomes from employment?}

Immigrants from non-Western countries are overrepresented among the self-employed in Denmark and Sweden even if we control for a number of characteristics as shown above. But how are the conditions for the self-employed immigrants? In this section we will look at the incomes of the self-employed. We will start with some descriptive statistics and after that present results of income regressions, both for self-employed and employed. ${ }^{11}$

As can be seen from the descriptive statistics the incomes of self-employed in Denmark are substantially higher than those of their Swedish counterparts. Also when we study the incomes for all employed except the self-employed, differences between Denmark and Sweden are found but they are not of the same magnitude as for the self-employed. There are probably several explanations for these differences between the incomes of the selfemployed in the two countries. We will mention three here. First, in the Danish sample we have a few self-employed with very high incomes. In the Danish data also those who own businesses with many employees are included. If these individuals are excluded the difference diminishes, but only a minor part of the difference disappears. That other factors are important is also seen by studying the medians reported in the tables. Secondly, as mentioned before we have not included self-employed in Sweden who have their companies registered as a limited share company. On average, these firms are probably generating higher incomes for their owners. A third explanation is that the systems for taxes and social transfers differ between the two countries. ${ }^{12}$ In Denmark, the individual is the unit for determining payment of social transfer, in Sweden it is the household. It means that there are economic incentives in Denmark in businesses where several household members take part to ascribe the income to one person (to increase the possibility of getting social welfare) and in Sweden to divide the income declared to the authorities among the family members (to diminish the taxes).

\footnotetext{
${ }^{11}$ In the income regressions for self-employed we exclude farmers (natives are strongly overrepresented in this industry). We include controls for industry of the self-employed with manufacturing is the reference category.

${ }^{12}$ We would like to thank Nina Smith for providing us with this information.
} 
Table 8. Mean and median incomes for self-employed. Self-employed in the agricultural sector and those with negative or zero income from self-employment are excluded

\begin{tabular}{llcc}
\hline Self-employed & & Denmark & Sweden \\
\hline All & Mean & 126 946 & 472436 \\
& (standard dev.) & {$[98189]$} & {$[518291]$} \\
& Median & 109245 & 374305 \\
\hline Natives & Mean & 133881 & 488139 \\
& (standard dev.) & {$[100324]$} & {$[528159]$} \\
& Median & 116728 & 388777 \\
\hline Western immigrants & Mean & 124449 & 366090 \\
& (standard dev.) & {$[96572]$} & {$[350594]$} \\
& Median & 100000 & 278480 \\
\hline Non-Western immigrants & Mean & 80898 & 205385 \\
& (standard dev.) & {$[67112]$} & {$[184186]$} \\
& Median & 65869 & 160403 \\
\hline
\end{tabular}

Note: All values are in SEK. The average currency rate in 1999 has been used to convert the Danish incomes.

Table 9. Mean and median income for wage-earners. Self-employed, farmers, and those with negative or zero income are excluded

\begin{tabular}{llcc}
\hline Wage-earners & & Denmark & Sweden \\
\hline All & Mean & 219587 & 283759 \\
& (standard dev.) & {$[151953]$} & {$[157698]$} \\
& Median & 203101 & 271183 \\
\hline Natives & Mean & 221232 & 285742 \\
& (standard dev.) & {$[143360]$} & {$[157485]$} \\
& Median & 204318 & 272711 \\
\hline Western immigrants & Mean & 224036 & 285577 \\
& (standard dev.) & {$[289423]$} & {$[195258]$} \\
& Median & 204761 & 271922 \\
\hline Non-Western immigrants & Mean & 180779 & 204314 \\
& (standard dev.) & {$[107198]$} & {$[119489]$} \\
& Median & 173778 & 212241 \\
\hline
\end{tabular}

Note: All values are in SEK. The average currency rate in 1999 has been used to convert the Danish incomes.

\section{Income regressions}

The next step is to estimate income regressions with log income as the dependent variable. Non-Western immigrants have are significantly lower incomes than natives in both Denmark and Sweden. In both Denmark and Sweden, the coefficients for selfemployed immigrants who have been in the host country for five years or more as well as for those who have lived in the country for less than five years are large and negative. 
The explanation for that also those who have lived in the host country five years or more have low incomes, could be that many of the immigrants who become self-employed are not making the choice due to good prospects as self-employed but because they have difficulties in finding a job. Such difficulties could be explained by differences in unobserved characteristics or discrimination, rather than as evidence that they prefer selfemployment instead of regular employment. In Denmark we find negative coefficients, but smaller, also for Western immigrants.

For second generation immigrants we do not find any significant effects on the income from self-employment in Sweden, neither for non-Western or Western immigrants. In Denmark there is a negative effect on the income from self-employment for second generation immigrants from non-Western immigrants. 
Table 10. Income regressions for the self-employed. Dependant variable is the log of income from self-employment. The self-employed in the agricultural sector are excluded. Robust standard errors in parentheses

\begin{tabular}{|c|c|c|c|c|c|c|}
\hline Variables & & lll & & den & Denmark & \\
\hline Living in Sweden & -1.215 & $(0.0322) * * *$ & & & & \\
\hline Age & 0.086 & $(0.0128) * * *$ & 0.113 & $(0.0216) * * *$ & 0.057 & $(0.0150)^{* * *}$ \\
\hline Age squared/1000 & -0.992 & $(0.1455)^{* * *}$ & -1.326 & $(0.2458)^{* * *}$ & -0.640 & $(0.1703)^{* * *}$ \\
\hline Female & -0.434 & $(0.0411)^{* * *}$ & -0.393 & $(0.0726)^{* * *}$ & -0.432 & $(0.0470)^{* * *}$ \\
\hline $\begin{array}{l}\text { Both parents born in host country } \\
\text { One parent born in host country, one in a }\end{array}$ & reference & & reference & & reference & \\
\hline Western country & -0.125 & $(0.1005)$ & -0.078 & $(0.1210)$ & -0.335 & $(0.1576)^{* *}$ \\
\hline $\begin{array}{l}\text { One parent born in host country, one in a } \\
\text { non-Western country }\end{array}$ & 0.166 & $(0.1330)$ & 0.171 & $(0.1470)$ & 0.044 & $(0.3333)$ \\
\hline Both parents born in a Western country & -0.059 & $(0.2002)$ & -0.074 & $(0.2054)$ & (dropped) & \\
\hline $\begin{array}{l}\text { Both parents born in a non-Western } \\
\text { country }\end{array}$ & -0.111 & $(0.1927)$ & -0.090 & $(0.2138)$ & -0.405 & $(0.1069)^{* * *}$ \\
\hline $\begin{array}{l}\text { Born in a Western country - lived in the } \\
\text { host country for five years or more }\end{array}$ & -0.212 & $(0.1251)^{*}$ & -0.126 & $(0.1451)$ & -0.390 & $(0.2016)^{*}$ \\
\hline $\begin{array}{l}\text { Born in a Western country - lived in the } \\
\text { host country for less than five years }\end{array}$ & -0.170 & $(0.2001)$ & 0.503 & $(0.3734)$ & -0.446 & $(0.2588)^{*}$ \\
\hline $\begin{array}{l}\text { Born in a non-Western country - lived in } \\
\text { the host country for five years or more }\end{array}$ & -0.720 & $(0.0677) * * *$ & -0.571 & $(0.0863) * * *$ & -0.895 & $(0.01124)^{* * *}$ \\
\hline $\begin{array}{l}\text { Born in a non-Western country - lived in } \\
\text { the host country for less than five years }\end{array}$ & -1.347 & $(0.2658) * * *$ & -1.681 & $(0.5066)^{* * *}$ & -0.995 & $(0.1876)^{* * *}$ \\
\hline Primary school & -0.071 & $(0.0634)$ & & & & \\
\hline Upper secondary school & 0.061 & $(0.0595)$ & & & & \\
\hline Short higher education & reference & & & & & \\
\hline Long higher education & 0.297 & $(0.0789)^{* * *}$ & & & & \\
\hline Primary school less than 9 years SE & & & -0.037 & $(0.0856)$ & & \\
\hline Primary school $9(10)$ years SE & & & 0.010 & $(0.0651)$ & & \\
\hline Upper secondary less than 2 years SE & & & reference & & & \\
\hline Upper secondary 2 years or more SE & & & 0.087 & $(0.0706)$ & & \\
\hline Higher education less than 3 years SE & & & -0.074 & $(0.1121)$ & & \\
\hline Higher education 3 years or more SE & & & 0.115 & $(0.1070)$ & & \\
\hline Post graduate education SE & & & -1.520 & $(0.9395)$ & & \\
\hline Primary school DK & & & & & -0.072 & $(0.0982)$ \\
\hline Upper secondary school DK & & & & & reference & \\
\hline Vocational education DK & & & & & 0.126 & $(0.0956)$ \\
\hline Short higher education DK & & & & & 0.056 & $(0.1287)$ \\
\hline Medium-length higher education DK & & & & & 0.117 & $(0.1200)$ \\
\hline Long higher education DK & & & & & 0.513 & $(0.1152)^{* * *}$ \\
\hline Married & 0.172 & $(0.0340)^{* * *}$ & 0.123 & $(0.0514)^{* * *}$ & 0.223 & $(0.0446)^{* * *}$ \\
\hline Industry & Yes & & Yes & & Yes & \\
\hline Constant & 10.842 & $(0.2809) * * *$ & 9.132 & $(0.4759) * * *$ & 11.345 & $(0.3285) * * *$ \\
\hline $\mathrm{R}^{2}$ & 0.3690 & & 0.1195 & & 0.1669 & \\
\hline Number of observations & 5265 & & 2400 & & 2865 & \\
\hline
\end{tabular}

Note: $* * *$ Significant at the $1 \%$ level of significance. $* *$ Significant at the $5 \%$ level of significance.

* Significant at the $10 \%$ level of significance. 
Table 11. Income regressions for employed. Dependant variable is the log of income from employment. The self-employed and farmers are excluded. Robust standard errors in parentheses.

\begin{tabular}{|c|c|c|c|c|c|c|}
\hline \multirow{2}{*}{$\begin{array}{l}\text { Variables } \\
\text { Living in Sweden }\end{array}$} & \multicolumn{2}{|c|}{ All } & \multicolumn{2}{|c|}{ Sweden } & \multicolumn{2}{|c|}{ Denmark } \\
\hline & -0.259 & $(0.0034) * * *$ & & & & \\
\hline Age & 0.086 & $(0.0011)^{* * *}$ & 0.073 & $(0.0013) * * *$ & 0.109 & $(0.0020)^{* * *}$ \\
\hline Age squared/1000 & -0.932 & $(0.0138)^{* * *}$ & -0.740 & $(0.0158)^{* * *}$ & -1.239 & $(0.0246)^{* * *}$ \\
\hline Female & -0.379 & $(0.0030)^{* *}$ & -0.414 & $(0.0039)^{* * *}$ & -0.332 & $(0.0048)^{* * *}$ \\
\hline Both parents born in host country & reference & & & & & \\
\hline $\begin{array}{l}\text { One parent born in host country, one in a } \\
\text { Western country }\end{array}$ & -0.019 & $(0.0090)^{* *}$ & -0.008 & $(0.0097)$ & -0.033 & $(0.0215)$ \\
\hline $\begin{array}{l}\text { One parent born in host country, one in a } \\
\text { non-Western country }\end{array}$ & -0.043 & $(0.0224)^{*}$ & -0.019 & $(0.0240)$ & -0.091 & $(0.0563)$ \\
\hline Both parents born in a Western country & -0.023 & $(0.0151)$ & -0.012 & $(0.0151)$ & $-\mathbf{0 . 0 3 8 3}$ & $(0.0135)$ \\
\hline $\begin{array}{l}\text { Both parents born in a non-Western } \\
\text { country }\end{array}$ & -0.043 & $(0.0316)$ & -0.038 & $(0.0319)$ & -0.229 & $(0.1591)$ \\
\hline $\begin{array}{l}\text { Born in a Western country - lived in the } \\
\text { host country for five years or more }\end{array}$ & -0.056 & $(0.0095) * * *$ & -0.045 & $(0.0099) * * *$ & -0.157 & $(0.0282)^{* * *}$ \\
\hline $\begin{array}{l}\text { Born in a Western country - lived in the } \\
\text { host country for less than five years }\end{array}$ & -0.194 & $(0.0339)^{* * *}$ & -0.132 & $(0.0465) * * *$ & -0.256 & $(0.0483)^{* * *}$ \\
\hline $\begin{array}{l}\text { Born in a non-Western country - lived in } \\
\text { the host country for five years or more }\end{array}$ & -0.266 & $(0.0107)^{* * *}$ & -0.233 & $(0.0120)^{* * *}$ & -0.345 & $(0.0226)^{* * *}$ \\
\hline $\begin{array}{l}\text { Born in a non-Western country - lived in } \\
\text { the host country for less than five years }\end{array}$ & -0.532 & $(0.0333) * * *$ & -0.429 & $(0.0398) * * *$ & -0.590 & $(0.0477)^{* * *}$ \\
\hline Primary school & -0.343 & $(0.0050)^{* * *}$ & & & & \\
\hline Upper secondary school & -0.165 & $(0.0041)^{* * *}$ & & & & \\
\hline Short higher education & reference & & & & & \\
\hline Long higher education & 0.205 & $(0.0057)^{* * *}$ & & & & \\
\hline Primary school less than 9 years SE & & & -0.116 & $(0.0075) * * *$ & & \\
\hline Primary school $9(10)$ years SE & & & -0.058 & $(0.0064)^{* * *}$ & & \\
\hline Upper secondary less than 2 years SE & & & reference & & & \\
\hline Upper secondary 2 years or more SE & & & 0.128 & $(0.0059) * * *$ & & \\
\hline Higher education less than 3 years SE & & & 0.204 & $(0.0060)^{* * *}$ & & \\
\hline Higher education 3 years or more SE & & & 0.402 & $(0.0063)^{* *}$ & & \\
\hline Post graduate education SE & & & 0.658 & $(0.0175)^{* * *}$ & & \\
\hline Primary school DK & & & & & -0.218 & $(0.0117)^{* * *}$ \\
\hline Upper secondary school DK & & & & & reference & \\
\hline Vocational education DK & & & & & 0.020 & $(0.0106)^{*}$ \\
\hline Short higher education DK & & & & & 0.129 & $(0.0138)^{* * *}$ \\
\hline Medium-length higher education DK & & & & & 0.197 & $(0.0117)^{* * *}$ \\
\hline Long higher education DK & & & & & 0.398 & $(0.0137)^{* * *}$ \\
\hline Married & 0.072 & $(0.0036) * * *$ & 0.008 & $(0.0044)^{*}$ & 0.134 & $(0.0061)^{* * *}$ \\
\hline Constant & 10.827 & $(0.0231)^{* * *}$ & $\mathbf{1 0 . 5 7 7}$ & $(0.0275)^{* * *}$ & 10.202 & $(0.0372)^{* * *}$ \\
\hline $\mathrm{R}^{2}$ & 0.2411 & & 0.2424 & & 0.2191 & \\
\hline Number of observations & 155152 & & 83160 & & 71992 & \\
\hline
\end{tabular}

Note: ** Significant at the $1 \%$ level. * Significant at the 5\% level. * Significant at the $10 \%$ level. 


\section{Summary and conclusions}

In this study we have utilized two data sets, one for Denmark and one for Sweden, to study self-employment among immigrants in the two countries. Self-employment among immigrants has been widely discussed internationally. It has been interpreted both as a result of that immigrants with traditions favouring self-employment have succeeded in establishing themselves as self-employed, but also that immigrants who have problems in establishing themselves in the labour market are becoming self-employed as a last resort. We show that non-Western immigrants in both Denmark and Sweden are overrepresented among the self-employed. We also find that the self-employed immigrants have lower incomes than immigrants who have other types of employment. The differences are large, especially in Sweden. The results give some support to the hypothesis that the immigrants are becoming self-employed due to that they have difficulties in getting other types of employment.

\section{References}

Andersson P. and Wadensjö E. 2003. "En arbetslöshetsförsäkring för alla sysselsatta? Anställda i bemanningsföretag och egenföretagare". Arbetsmarknad \& Arbetsliv, Vol. 9. pp. 189-209.

Bager T. 2002. "Invandrervirksomheder I Danmark - med vægt på perioden siden 1980" in Erhvervshistorisk Årbog 2002, Erhvervsarkivet, Århus.

Bager T. and Rezaei S. 2001. "Immigrant businesses in Denmark: Captured in marginal business fields?" CESFO Working Paper 2001/1, Kolding.

Bager T. and Rezaei S. 2001a. Invandrervirksomheder i Danmark, CESFO Rapportserie III, Kolding.

Blanchflower D. G. 2000. "Self-employment in OECD countries", Labour Economics, Vol 7, pp. 471- 505.

Blume K., Gustafsson, B., Pedersen, P.J. and Verner, M. 2003. "A Tale of Two Countries: Poverty among Immigrants in Denmark and Sweden since 1984". WIDER Discussion Paper No. 2003/36.

Blume Jensen K., Skyt Nielsen H., Ejrnæs M. and Würtz A. 2004. "Self-Employment among Immigrants: A Last Resort?" in K. Blume, Integration of Immigrants in Danish Labour Market, Ph.D. thesis, Aarhus School of Business, Department of Economics. Borjas G. J. 1986. "The Self-Employment Experience of Immigrants". The Journal of Human Resources, Vol. 21, pp. 485-506.

Borjas G. J. and Bronars S. G. 1989. "Consumer Discrimination and Self-Employment". The Journal of Political Economy, Vol. 97, pp. 581-605. 
Clark K. and Drinkwater S. 2000. "Pushed out or pulled in? Self-employment among ethnic minorities in England and Wales". Labour Economics, Vol 7, pp. 603- 628.

Dohlmann C. 2001. "Self-employment among male immigrants in Denmark. Long-term unemployment and comparative advantages". The Danish National Institute of Social Research, Working Paper 08:2001.

Ekberg, J. and Hammarstedt M. 1999. "Egenföretagande bland invandrare". Arbetsmarknad \& Arbetsliv, Vol. 3, pp. 207-217.

Evans D. S. and Jovanovic B. 1989. "An Estimated Model of Entrepreneurial Choice under Liquidity Constraints". The Journal of Political Economy, Vol. 97, pp. 808-827. Fairlie R. W. and Meyer B. D. 1996. "Ethnic and Racial Self-Employment Differences and Possible Explanations". The Journal of Human Resources, Vol. 3, pp. 757-793.

Kihlstrom, R. and Laffont J-J. 1979. "A General Equilibrium Entrepreneurial Theory of Firm Formation Based Risk Aversion”. The Journal of Political Economy, Vol. 87, pp. 719-748.

Light I. 1984. "Immigrant and Ethnic Enterprise in North America". Ethnic and Racial Studies, Vol. 7, pp. 195-216.

Lindh T. and Ohlsson H. 1996. "Self-employment and Windfall Gains: Evidence from the Swedish Lottery". The Economic Journal, Vol. 106, pp. 1515-1526.

Lindh T. and Ohlsson H. 1997. Egenföretagande och manna från himlen, Rapport till ESO Ds 1997:71.

Moore R. L. 1983. "Employer Discrimination: Evidence from Self-Employed Workers". The Review of Economics and Statistics, Vol. 65, pp. 496-501.

Najib A. B. 1999. Myten om invandrarföretaget. En jämförelse mellan invandrarföretagande och övrigt företagande i Sverige, Svenska EU Programkontoret, NUTEK and Rådet för arbetslivsforskning, Stockholm.

Rezaei S. 2002. "Invandrerejede virksomheder", AMID Working Paper Series 8/2002.

Rezaei S. 2004. Erhvervsdynamik blandt indvandrare: Selverhverv og netvcerksrelationer - bolkering eller afscet for socio-økonomisk mobilitet?, Syddansk Universitetsforlag,

Odense.

Wadensjö E. and Orrje H. 2002. "Immigrants and self-employment in Denmark", Working paper, Swedish Institute for Social Research, Stockholm University.

Yuengert A. M. 1995. "Testing Hypotheses of Immigrant Self-Employment". The Journal of Human Resources, Vol. 30, pp. 194-204. 